\title{
Pott's puffy tumour: a forgotten diagnosis
}

\author{
Stephen L Ball, ${ }^{1,2}$ Sean Carrie ${ }^{1}$
}

${ }^{1}$ Department of ENT Surgery, Freeman Hospital, Newcastle upon Tyne, Tyne \& Wear, UK ${ }^{2}$ Institute of Cellular Medicine, Newcastle University, Newcastle upon Tyne, Tyne \& Wear, UK

\section{Correspondence to}

Stephen L Ball,

s.l.ball@ncl.ac.uk

Accepted 16 September 2015

\section{DESCRIPTION}

A man presented to his local plastic surgery department, with a history of headache and recurrent abscesses in the soft tissues of the forehead (figure 1). He was initially treated with repeated aspiration and antibiotics, but the lesion failed to resolve. A diagnosis of chronic frontal sinusitis with osteomyelitis, eponymously called Pott's Puffy tumour, ${ }^{1}$ was made after CT scan (figure $2 \mathrm{~A}$ ) and MRI (figure 2B). The patient was then taken to the theatre for endoscopic sinus surgery and frontal sinus trephines to drain the abscess and ensure adequate sinus ventilation. Microbiological analysis

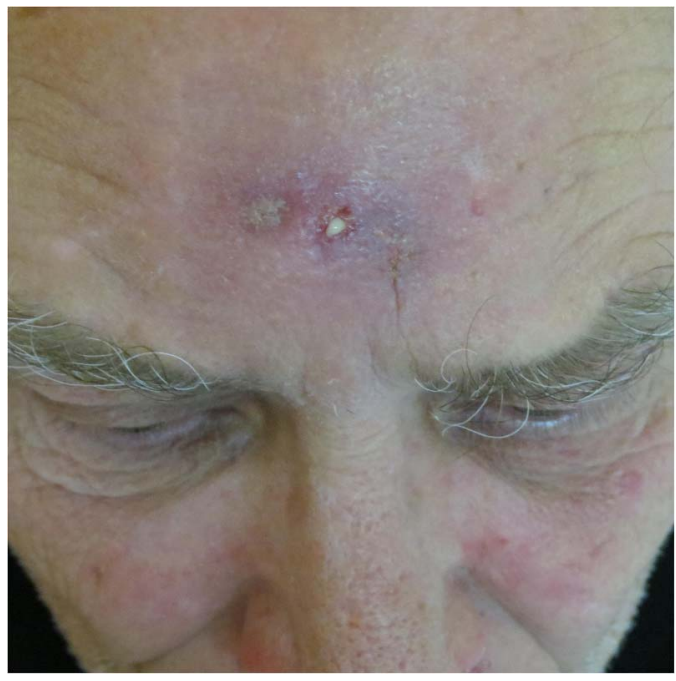

Figure 1 Clinical photograph showing discharging frontal sinus abscess. The surrounding tissues are swollen, erythaematous and boggy. of the abscess pus confirmed growth of Streptococcus anginosus. In total, a 3-month course of metronidazole and moxifloxacin antibiotic therapy was completed to treat the frontal bone osteomyelitis. Repeat CT scan showed wellpneumatised sinuses and no disease recurrence (figure 3). The patient was followed up for 1 year to ensure resolution and remained symptom free.

In the initial stages of Pott's puffy tumour, misdiagnosis of a simple infected skin cyst may occur. Lesions in this region should be referred for an ENT (ear, nose and throat) opinion where endoscopic nasal assessment and cross-sectional radiological imaging will be performed. In the diagnostic work up for potential intracranial complications of rhinosinusitis, a combination of CT scan and MRI are complementary; CT scan provides a better

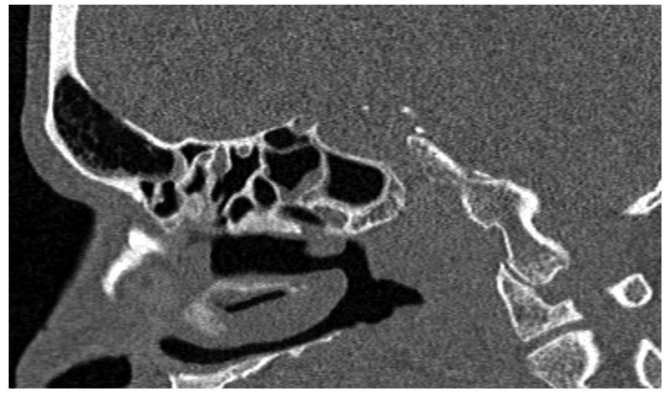

Figure 3 Post-treatment sagittal CT scan demonstrating a well-pneumatised frontal sinus; the other paranasal sinuses are also healthy with no disease recurrence. The imaging improvement can lag behind clinical response, though in this case, a sufficient time window has elapsed between treatment and repeat CT scan.

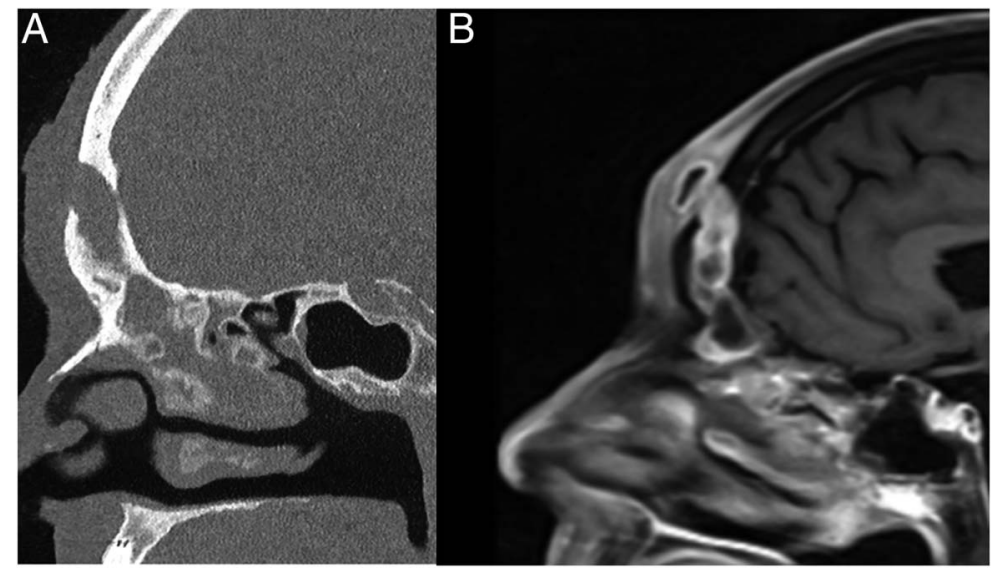

Figure 2 (A) Sagittal CT of the paranasal sinuses demonstrating an opacified frontal sinus, erosion of the anterior wall of the frontal sinus and contiguous abscess of the soft tissues of the forehead. (B) Sagittal T1-weighted MRI with contrast of the paranasal sinuses showing forehead soft tissue abscess with enhancement in continuity with opacified frontal sinus. 
assessment of the bony involvement, and MRI provides better characterisation of soft tissue detail and, importantly, can exclude intracranial involvement of frontal sinusitis.

\section{Learning points}

- Pott's puffy tumour is a rare complication of frontal sinusitis.

- Lesions on the forehead, especially with any sinonasal symptoms or headache, should be referred for an ENT (ear, nose and throat) opinion with nasal endoscopy and cross-sectional imaging.

- Treatment of Pott's puffy tumour normally consists of long-term antibiotics, with surgical drainage, debridement and reconstruction, depending on disease severity.
The treatment consists of a combination of long-term antibiotics, with surgical drainage, debridement and reconstruction, depending on disease severity. ${ }^{2}$

Acknowledgements The authors would like to acknowledge the help and participation of our patient in the preparation and reviewing of the case report.

Competing interests None declared.

Patient consent Obtained.

Provenance and peer review Not commissioned; externally peer reviewed.

\section{REFERENCES}

1 Pott P. The chirurgical works of Percival Pott, F.R.S. Vol 1. London, UK: Woods and Innes, 1808.

2 Akiyama K, Karaki M, Mori N. Evaluation of adult Pott's puffy tumor: our five cases and 27 literature cases. Laryngoscope 2012;122:2382-8.

Copyright 2015 BMJ Publishing Group. All rights reserved. For permission to reuse any of this content visit

http://group.bmj.com/group/rights-licensing/permissions.

BMJ Case Report Fellows may re-use this article for personal use and teaching without any further permission.

Become a Fellow of BMJ Case Reports today and you can:

- Submit as many cases as you like

- Enjoy fast sympathetic peer review and rapid publication of accepted articles

- Access all the published articles

- Re-use any of the published material for personal use and teaching without further permission

For information on Institutional Fellowships contact consortiasales@bmjgroup.com

Visit casereports.bmj.com for more articles like this and to become a Fellow 